SIR,-After reading recent favourable reports concerning buccal oxytocin ${ }^{1-3}$ many obstetricians will have chosen this simpler way of inducing labour. The more conservative among us have awaited news of its dangers.

Your leading article (19 September, p. 705) sounded a warning note which might have been louder. The report of a case of ruptured uterus, accompanied by photographs which call to mind the bad old days of intramuscular Pitocin (oxytocin) (12 September, p. 689) and the further report (3 October, p. 876) of two alarming cases of fierce uterine overactivity are surely good reasons for calling a halt.

Pitocin (oxytocin) and its synthetic equiva- lents are such extremely potent oxytocics, and hypersensitivity to them is so well known, that they should only be given by continuous intravenous infusion and then only under close supervision.

I agree with Dr. F. A. Best (10 October, p. 942) that the introduction of buccal oxytocin is a retrograde step and I believe that its use should be abandoned.-I am, etc.,

\section{Horton General Hospital, \\ J. M. Gate.}

Banbury, Oxon.

\section{REFERENCES}

Elstein, M., and Wright, H. P.. F. Obstet. Spence, D. N., and Chalmers, J. A., Lancet, Blair, R. G., ibid., 1964, 1, 637

\title{
Treatment of Recurrent Herpes
}

SIR, $-D r$. B. E. Juel-Jensen and Dr. F. O. MacCallum (17 October, p. 987) are to be congratulated on their excellent presentation of a double-blind-control trial using idoxuridine cream in herpes simplex of the face. Their paper shows that a $0.5 \%$ cream of 5-iodo-2'-deoxyuridine applied six-hourly has no beneficial effect on the lesions of herpes simplex.

Of especial interest is their finding that the natural history of the lesions was completely changed when an idoxuridinecontaining fluid was brought into intimate contact with the affected cells by using a modified air-gun for intradermal injection. The results of their further double-blindcontrol trial using this method will be awaited with keen interest.

In our paper on the treatment of herpes simplex with idoxuridine ${ }^{1}$ the first 11 of our 13 cases were treated with $0.1 \%$ topical solution rubbed in hourly. Two further cases were treated with the cream applied four times daily with apparently good results, though in these patients the lesions had already been present for three to four days before the commencement of treatment Our subsequent experience with idoxuridine led us to believe that both cream and solution are ineffective unless well rubbed in at least two-hourly.

The variability of the natural history of herpes simplex, and the difficulty in seeing patients in the early phase of an attack, make the assessment of treatment difficult. This latter problem has been overcome by our Oxford colleagues by obtaining their patients for investigation from members of their hospital staff; an idea we have belatedly adopted ourselves in our own double-blindcontrol trial which is proceeding.-We are, etc.,

\section{Hove, Sussex. \\ S. P. Hall-SMith REFERENCE 1 Hall-Smith, S. P., Corrigan, M. J., and Gilkes,
M. J., Brit. med. J., 1962, 2, 1515 .}

SIR,-In view of the recent correspondence on the treatment of recurrent herpes simplex, I feel my experiences with 5-iodo2 '-deoxyuridine (idoxuridine, I.D.U.) may be of interest.

Initially, 29 patients with herpes simplex of the skin were treated, the early ones with the ophthalmic solution and later ones with idoxuridine made up in an ointment of $0.5 \%$ strength. Of these, 24 patients were thought to have responded satisfactorily. In general the patients were seen within 24 hours of the onset of the eruption and the medicamen was applied three-hourly or occasionally thrice daily. In the few patients who had recurrent herpes simplex and found idoxuridine satisfactory treatment of the recurrence was equally successful. As a result of this a double-blind trial was carried out with the following results:

$\begin{array}{llccc}\text { fdoxuridine } & \begin{array}{c}\text { Satis- } \\ \text { factory }\end{array} & \begin{array}{c}\text { Unsatis- } \\ \text { factory }\end{array} & \text { No change } \\ \text { Control } & \ldots & 14 & 6 & 3 \\ \text { Con } & \ldots & 8 & 1\end{array}$

Only 16 of the patients using idoxuridine were seen within 24 hours of the onset of the eruption. A feature of the patients who responded to idoxuridine was the early relief of soreness and itching, this being noticed in all 14 of the satisfactory test patients and in only 6 of the control group. Of 6 patients who had recurrent episodes of erythema multiforme, apparently precipitated by a preceding attack of herpes simplex, 4 found that idoxuridine cured their herpes simplex and no subsequent attack of erythema multiforme appeared; one found no effect on his herpes or his erythema and one showed an improvement in his herpes with no effect on the . erythema.

Idoxuridine was also tried on other virus lesions: 4 patients with herpes zoster, of whom one reported dramatic relief from pain in twelve hours; 10 patients with verruca vulgaris with no improvement in any; one patient with perianal warts who improved quickly ; one patient with molluscum contagiosum, unchanged after two weeks' therapy; and four patient with plane warts who cleared within weeks after months of unsuccessful therapy. However, the latter condition is well known to be susceptible to psychological influences. In view of the early successes of idoxuridine, I agree with Mr. Gilkes (26 September, p. 817) that this substance should be tried when dealing with recurrent herpes simplex, especially if the lesion is seen within hours of the onset.

My thanks are due to Dr. I. B. Sneddon and Dr. R. E. Church, of Sheffield Royal Infirmary, for permission to use their patients, and also to Smith, Kline and French Laboratories Ltd. for provision of the idoxuridine and help in the trial.

$$
\begin{aligned}
& \text {-I am, etc., } \\
& \begin{array}{c}
\text { Skin Department, } \\
\text { The General Infirmary, } \\
\text { Leeds 1. }
\end{array} \\
& \text { T. W. STEWART. }
\end{aligned}
$$

SIR,-Your leading article on treatment of recurrent herpes (17 October, p. 960) draws attention to a paper by Drs. B. E. Juel-Jensen and F. O. MacCallum (17 October, p. 987) showing that 5-iodo-2' deoxyuridine (5-I.D.U.) was found to have no therapeutic benefit in a double-blindcontrolled trial. It also states that similar double-blind trials should be carried out to confirm this work. Such a trial has, in fact, already been done in America by Burnett and Katz, ${ }^{1}$ who published similar findings in the fournal of Investigative Dermatology in January 1963. This paper appeared one month after the publication in this country by Hall-Smith and others, ${ }^{2}$ who claimed success with this drug in the treatment of herpes simplex skin infections. In other words, this American drug was originally tested there and later found to be ineffective in herpes simplex skin infections some time before trials in this country had seriously got under way. In spite of this the leading article calls for more double-blind-controlled trials to confirm what has already been reported in several publications-that in the majority of cases idoxuridine appears to have no effect on the rate of healing of these lesions and is probably no better than any other remedy used for this purpose.

The leading article also suggests that psychological factors are eliminated in a double-blind-controlled trial, but surely a placebo given as a control has a psychological effect whether it is administered blindly or otherwise ? A double-blind-controlled trial was really designed to eliminate bias on the part of the investigator, but even then it still does not prevent guesses from being made which can affect the final interpretation of results. Investigators may even possess some form of occult vision in a trial described as "blind," since it is questionable whether a trial performed on a group of selected cases in which treatment is given at a particular time will be as blind as one performed on a random sample. The results obtained from two such groups would probably be as different as those obtained from similar groups in a public opinion poll. From a statistical point of view it would also appear that a better assessment of treatment can be made if the total number of control cases in a trial is equal to the number under test, particularly when studying rates of healing in herpes simplex lesions, which vary greatly irrespective of treatment.

Finally, it is interesting to note that Drs. Shiona Sowa and Sowa (17 October, p. 989) found that idoxuridine had no therapeutic benefit on TRIC agent isolated from cases of trachoma, since it has also been found to have no beneficial effect in the treatment of non-gonococcal urethritis, ${ }^{3}$ in which Dunlop and others ${ }^{4}$ have recently isolated TRIC agent.-I am, etc.,

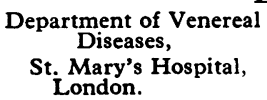

Burnett, J. W., and Katz, S. L., f. invest. Derm. $963,40,7$.

Hall-Smith, S. P., Corrigan, M. J., and Gilkes, Hutfield, D. C., Brit. f. vener. Dis., 1964, 40 , 146. - Dunlop, E. M. C., Jones, B. R., and Khalaf Al- 